\title{
Epidemiology of Child's Ocular Globe Injury: A Retrospective Study at the University Teaching Hospital-Campus of Lomé (Togo)
}

\author{
Nidain Maneh ${ }^{1,2}$, Abou-Bakr Sidik Domingo², Kassoula Batomaguela Nonon Saa1, \\ Vonor Kokou', Agba Aide Isabelle², Ayena Koffi Didier', Banla Meba',2, Balo Komi Patrice ${ }^{1}$ \\ ${ }^{1}$ Faculty of Health Sciences, University of Lome, Lomé, Togo \\ ${ }^{2}$ Department of Ophthalmology, The University Teaching Hospital Campus of Lomé, Lomé, Togo \\ Email:manehnid@hotmail.fr
}

How to cite this paper: Maneh, N., Domingo, A.-B.S., Saa, K.B.N., Kokou, V., Isabelle, A.A., Didier, A.K., Meba, B. and Patrice, B.K. (2017) Epidemiology of Child's Ocular Globe Injury: A Retrospective Study at the University Teaching Hospital-Campus of Lomé (Togo). Open Journal of Ophthalmology, 7, 8-13.

https://doi.org/10.4236/ojoph.2017.71002

Received: December 2, 2016

Accepted: January 15, 2017

Published: January 18, 2017

Copyright (ङ 2017 by authors and Scientific Research Publishing Inc. This work is licensed under the Creative Commons Attribution International License (CC BY 4.0).

http://creativecommons.org/licenses/by/4.0/

\begin{abstract}
Aim: To study clinical and epidemiological characteristics of child's ocular injuries. Patients and Method: Retrospective study on medical records of children suffering from traumatic injuries of the ocular globe presented to the Campus Teaching Hospital (CHU Campus) of Lomé from 3 January 2015 to 30 June 2016 (18 months). Age, sex, nature of the traumatising agent, consultation delay and the width of the injury (zone I, II or III), the classification of ocular trauma, according to "Birmingham Eye Trauma Terminology (BETT) system", connected lesions have been studied. Results: Twenty children about $46.51 \%$ children presented for ocular trauma have been suffering from a globe injury. The average age was 6.68 years with the extremes of 1 year and 12 years; the age bracket of 0 - 5 years was more represented (45\%); predominance was more from the female with a sex-ratio $=$ 0.67. Eighty percent of the children were from rural areas while twenty from urban areas. The delay of consultation was less than 24 hours in $40 \%$ of cases and $15 \%$ consulted between $24 \mathrm{~h}$ and $72 \mathrm{~h}$ after the trauma. Traumatisms were entirely unilateral and penetrating within a majority of 15 (75\%) cases of which a "stick" is the traumatising agent of the most frequent (40\%). The seat of the injury was the zone I (85.71\%) and zone II (14.29\%). Connected lesions were dominated by iris hernia 7 (35\%) and traumatic cataract $6(30 \%)$. Conclusion: children's traumas were high predominantly and they came in majority from rural zones. Prevention through awareness remains the best treatment.
\end{abstract}

\section{Keywords}

Child, Injury, Globe, Ocular, Lomé 


\section{Introduction}

Ocular traumas represent the first cause of child's blindness [1]. Children make the highest proportion of people suffering from serious globe traumas [2]. Globe injuries are serious traumas as they can jeopardise children's visual function. The awareness of epidemiological characteristics of these injuries with children will certainly help in the reduction of their incidences by avoiding such accidents. Since January 2015, Lomé Campus Teaching Hospital has a paediatric ophthalmology unit for diagnosis and treatment. The aim of this study is to analyse clinical and epidemiological characteristics of child's globe injuries from a retrospective study since the institution of this unit.

\section{Patients and Method}

We have conducted a retrospective study upon 18 months (2 January to 30 June 2016) as far as the exhaustiveness of the records of children's (0 to 17 years) global injuries received in the unit of ophthalmology of CHU Campus of Lomé. Data received throughout our census were based upon age, gender, circumstance of accident, nature of the traumatising agent and the delay of consultation. In most case, the criterion of visual acuity was not considered. The ophthalmological clinical examination has helped a classification of the wound following the "Birmingham Eye Trauma Terminology system (BETT)" [3] in matters of penetrating, perforating or globe rupture trauma. We have proceeded following the Ocular Trauma Classification Group [4]: wound involvement is isolated to the cornea in zone I, full-thickness wound involves the sclera no more posteriorly than $5 \mathrm{~mm}$ from the corneoscleral limbus in zone II and full-thickness wound is posterior to zone II in zone III.

\section{Results}

\section{Demographic}

Twenty children $(46 \%, 51 \%)$ counted among the 43 children suffering from ocular trauma during the study period. The average age was 6.68 years with extreme of 1 year and 12 years, the bracket of those less than 5 years was noticed with $45 \%$ of these children. A sex-ratio of 0.61 (8/13) of female predominance has been noticed (Table 1 ). It has been also noticed that eighty per cent of the children were coming from rural areas and 20 per cent from the urban areas.

\section{Clinical}

Forty per cent of the children ( 8 cases) have come to hospital instantly in the

Table 1. Distribution of children by sex and age.

\begin{tabular}{cccc}
\hline & Male (\%) & Female $(\%)$ & Total \\
\hline$[0,5]$ & $3(15)$ & $6(30)$ & $9(45)$ \\
{$[5,10]$} & $4(20)$ & $2(10)$ & $6(30)$ \\
{$[10,17]$} & $1(5)$ & $4(20)$ & $5(25)$ \\
Total & $8(40)$ & $12(60)$ & $20(100)$ \\
\hline
\end{tabular}


24 hours that followed their trauma. Fifteen percent (3 cases) have been received for ophthalmological consultation between the 24th and 72 th hours while $45 \%$ ( 9 cases) after 72 hours. The nature of the traumatising agent is variable but it is mainly sharp for $75 \%$ (15 cases) they are mainly "sticks" for 35\% (7 cases). Fifteen $(75 \%)$ traumatisms were penetrating, 3 (10\%) cases were a breaking of the globe and two of which the mechanism was not specified by their parents (Table 2).

The seat of the injury was zone I in $85.71 \%$ and zone II in $14.29 \%$. Ocular traumas were all unilateral of which 7 cases on the right eye and 13 cases on the left eye. Lesions associated were dominated by iris prolapse with 7 (35\%) cases of variable scale (Figure 1), post traumatic cataract that quickly grow in $6(30 \%)$ cases and the hyphema in $4(20 \%)$ cases mostly associated to the iris prolapse (Table 3).

Table 2. Natures of traumatising agent.

\begin{tabular}{ccc}
\hline & Number of patients & $\%$ \\
\hline Sharp & 7 & 35 \\
Bit of wood & 1 & 5 \\
Edges of scissors & 1 & 5 \\
Knife & 1 & 5 \\
Piece of CD & 1 & 5 \\
Broom twig & 1 & 5 \\
Piece of bone & 1 & 5 \\
Edge of pencil & 1 & 5 \\
\hline Piece of broken bottle & & 15 \\
\hline Blunts & 3 & 10 \\
\hline Stick & 2 & 15 \\
\hline Non identified & & 5 \\
\hline
\end{tabular}

CD: compact disc.



Figure 1. Wounds in zone I with iris prolapsed. 
Table 3. Associated lesions to global injuries.

\begin{tabular}{ccc}
\hline & Number of patients & $\%$ \\
\hline Iris prolapse & 7 & 35 \\
Cataract & 6 & 30 \\
Hyphema & 4 & 20 \\
Others $^{+}$ & 3 & 15 \\
\hline
\end{tabular}

${ }^{+}$vitreous way out, bulb physics and eyelid wound.

\section{Discussion}

In 18 months 20 cases of children's global injuries were identified that is more than 13 cases per year a really high rate as compared to Beby et al. [5] 57 cases (11 cases/year) within 5 years and Bunting et al. [6] 131 (7 cases/year) within 17 years. As the Campus Teaching Hospital of Lomé is the only one hospital in Togo endowed with a paediatric ophthalmology unit, this was put in service since January 2015. All of the southern part of Togo and even the whole country paediatric ophthalmological emergencies are referred thereto.

Children of school age were more concerned which in fact is in accordance with the review [6] [7] [8] [9] as they are more involved in children's games and the ignorance of the potential accidents that can happen while manipulating some materials. Contrarily to various studies which confirm male predominance [9] [10], our study has rather noted female predominance. Are females becoming more and more interested in violent games just as young boys? Only 8 over 20 cases (40\%) have been received in emergency in 24 hours, this delay of consultation has been late compared to Ojabo et al. [10] study that reported 71 (80\%) cases over 89 cases in 24 hours. The fact that children suffering from trauma are not transferred in time to be taken care of is due to the fact that the mostly live far away from the hospital. The traumatising agents were generally sharp. This is why globe injuries are particularly penetrating at $75 \%$ but only $10 \%$ for rupture in our study. Other authors have come up with different rates such as $54 \%$ and $65.7 \%$ for penetrating trauma $34 \%$ and $22.4 \%$ for rupture of the globe [11] [12]. But Gilbert et al. [13] in their study have rather found that globe ruptures were more frequent with a varying frequency from $39 \%$ to $43.2 \%$. Bit of wood was the first cause contrarily to the study of Beby et al. [5] which reported knife or scissors in $17.5 \%$ and the wood in $14 \%$. The fact that most of these children are coming from rural zone and the fact that sticks are mainly used in their games and also as they are involved in farm activities can be the major explanation to these accidents. The fact that the wounds are unilateral is not new to journals [5] [12]. Various studies [7] [12] [14] have pointed out the predominance of injury in zone I at $64 \%, 58 \%$ and $61.8 \%$ as this study shows (85.71\%). These very studies also show that $31.4 \%$ and $4 \%$ of injury in zone III contrarily to our study that finds no wound related in zone III. The high proportion of the wounds in zone I may be understood by the predominance of the perforating trauma. Iris prolapse and the cataract were found as associated lesions but at relatively low rates respectively in 35\% and 30\%. Other study has shown that 
uveal prolapse is the first lesion connected in $93 \%$ of the cases second by the cataract in $43 \%$ of the cases but at much more high rate [7].

\section{Conclusion}

Globe injuries were in majority penetrating traumas due to the manipulation of sharpen materials in rural zones. The best treatment remains prevention by forbidding violent games in order to avoid jeopardising visual functions and children's schooling.

\section{Conflict of Interest}

The authors declare no conflict of interest.

\section{Ethical Approval}

Approval for the study was obtained from the national medical ethic committee.

\section{References}

[1] Tok, O., Tok, L., Ozkaya, D., et al. (2011) Epidemiological Characteristics and Visual Outcome after Open Globe Injuries in Children. Journal of AAPOS, 15, 556561. https://doi.org/10.1016/j.jaapos.2011.06.012

[2] Sul, S., Gurelik, G., Korkmaz, S., et al. (2016) Pediatric and Factors Associated with Poor Visual and Anatomical Success. Graefe's Archive for Clinical and Experimental Ophthalmology, 254, 1405. https://doi.org/10.1007/s00417-015-3087-y

[3] Kuhn, F., Morris, R., Witherspoon, C.D. and Mester, V. (2004) The Birmingham Eye Trauma Terminology System (BETT). Journal Français d Ophtalmologie, 27, 206-210. https://doi.org/10.1016/S0181-5512(04)96122-0

[4] Pieramici, D., Sternberg, P., Aaberg, T., et al. (1997) Ocular Trauma Classification Group. A System for Classifying Mechanical Injuries of the Eye (Globe). American Journal of Ophthalmology, 123, 820-831. https://doi.org/10.1016/S0002-9394(14)71132-8

[5] Beby, F., Kodjikian, L., Roche, O., et al. (2006) Traumatismes Oculaires Perforants de l'Enfant. Étude rétrospective de 57 cas. Journal Français d' Ophtalmologie, 29, 20 23. https://doi.org/10.1016/S0181-5512(06)73742-1

[6] Bunting, H., Stephens, D. and Mireskandari, K. (2013) Prediction of Visual Outcomes after Open Globe Injury in Children: A 17-Year Canadian Experience. Journal of AAPOS, 17, 43-48. https://doi.org/10.1016/j.jaapos.2012.10.012

[7] Read, S.P. and Cavuoto, K.M. (2016) Traumatic Open Globe Injury in Young Pediatric Patients: Characterization of a Novel Prognostic Score. Journal of AAPOS, 20, 141-144. https://doi.org/10.1016/j.jaapos.2015.11.008

[8] Tok, O., Tok, L., Ozkaya, D., Eraslan, E., Ornek, F. and Bardak, Y. (2011) Epidemiological Characteristics and Visual Outcome after Open Globe Injuries in Children. Journal of AAPOS, 15, 556-561. https://doi.org/10.1016/j.jaapos.2011.06.012

[9] Liu, X., Liu, Z., Liu, Y., et al. (2014) Determination of Visual Prognosis in Children with Open Globe Injuries. Eye, 28, 852-856. https://doi.org/10.1038/eye.2014.108

[10] Ojabo, C.O., Malu, K.N. and Adeniyi, O.S. (2015) Open Globe Injuries in Nigerian Children: Epidemiological Characteristics, Etiological Factors, and Visual Outcome. Middle East African Journal of Ophthalmology, 22, 69-73. https://doi.org/10.4103/0974-9233.148352 
[11] Lesniak, S.P., Bauza, A., Son, J.H., et al. (2012) Twelve-Year Review of Pediatric Traumatic Open Globe Injuries in an Urban U.S. Population. Journal of Pediatric Ophthalmology and Strabismus, 49, 73-79. https://doi.org/10.3928/01913913-20110712-02

[12] Baba, A., Zbiba, W., Korbi, M. and Mrabet, A. (2015) Epidemiology of Open Globe Injuries in the Tunisian Region of Cap Bon: Retrospective Study of 100 Cases. Journal Français d Ophtalmologie, 38, 403-408. https://doi.org/10.1016/j.jfo.2014.11.011

[13] Gilbert, C.M., Soong, H.K. and Hirst, L.W. (1987) A Two-Year Prospective Study of Penetrating Ocular Trauma at the Wilmer Ophthalmological Institute. Annals of Ophthalmology, 19, 104-106.

[14] Konforty, N., Lior, Y., Levy, J., et al. (2016) Epidemiology, Clinical Caracteristic Factors, and Visual Outcomes in Patients with Open Ocular Injuries and Intraocular Foreign Bodies. Harefuah, 155, 267-271.

Submit or recommend next manuscript to SCIRP and we will provide best service for you:

Accepting pre-submission inquiries through Email, Facebook, LinkedIn, Twitter, etc. A wide selection of journals (inclusive of 9 subjects, more than 200 journals) Providing 24-hour high-quality service User-friendly online submission system Fair and swift peer-review system Efficient typesetting and proofreading procedure Display of the result of downloads and visits, as well as the number of cited articles Maximum dissemination of your research work

Submit your manuscript at: http://papersubmission.scirp.org/

Or contact ojoph@scirp.org 